\title{
Imipenem-Cilastatin Monotherapy in Severe Infections Accompanying Hematological Malignancies
}

\author{
Akio URABE*,**, Fumimaro TAKAKU* and Hideaki MizoGUCHI***
}

\begin{abstract}
Imipenem-cilastatin (imipenem 1 to $4 \mathrm{~g}$ /day) was administered to patients with severe infections accompanying granulocytopenia in hematological malignancies. Monotherapy with imipenem-cilastatin was effective in $62.1 \%$ of the patients, and also effective even they were severely neutropenic. When imipenemcilastatin was administered as the first-choice therapy, the efficacy was much better, at 73.3\%. Both Grampositive and Gram-negative infections were curable by the monotherapy with imipenem-cilastatin.
\end{abstract}

Key words: Granulocytopenia, Antibiotics, Chemotherapy

Severe neutropenia and immunodeficiency often complicate hematological malignancies, and the treatment of the accompanying infections plays an important role in the management of hematological diseases (1). Recently many new drugs and regimens for the treatment of hematological malignancies have been introduced, and the curative rates of the diseases have become much better than before. However, strong cancer chemotherapy has inevitably brought about severe myelosuppression, and the duration of granulocytopenia has become longer. Consequently, patients with hematological malignancies, such as leukemias and lymphomas, are easily susceptible to various life-threatening severe infections during and after the chemotherapy (2).

In the treatment of infections accompanying hematological malignancies, the appropriate empiric therapy is critical because the therapy of infections must be urgent (3). We have conducted a multiinstitutional study for the evaluation of the efficacy of imipenem-cilastatin for the treatment of severe infections accompanying granulocytopenia in various hematological malignancies.

\section{PATIENTS AND METHODS}

Patients with hematological disorders who suffered from various infections were entered in this study from December 1987 to April 1989 in 18 institutions in Tokyo area. When patients showed signs of infections or had febrile episodes of unknown origin, imipenem-cilastatin (imipenem 1-4 g/day) was intravenously administered by drip infusion 2 to 4 times a day. Various bacteriological examinations were performed before and after the administration of imipenem-cilastatin. Bacteriological and clinical signs, and hematological and biochemical parameters were monitored during and after the therapy.

The efficacy of imipenem-cilastatin was determined based on the following criteria:

Excellent

The fever returns to normal temperature within 3 to 4 days, and is maintained for 3 to 4 days, and signs and symptoms of infections improve. Good

From *The Third Department of Internal Medicine, Faculty of Medicine, University of Tokyo, Tokyo, **Department of Medicine, Teikyo University Mizonokuchi Hospital, Kawasaki and ***Department of Medicine, Tokyo Women's Medical College, Tokyo

Received for publication August 3, 1990; Accepted for publication January 7, 1991

Reprint requests should be addressed to Akio Urabe, MD, The Third Department of Internal Medicine,

Faculty of Medicine, University of Tokyo, 7-3-1 Hongo, Bunkyo-ku, Tokyo 113, Japan 
The fever is significantly reduced within 3 to 4 days, and is maintained for 3 to 4 days, and signs and symptoms of infections improve.

\section{Partial}

The fever is reduced within 6 days, and signs and symptoms of infections improve.

\section{Ineffective}

The fever remains elevated, and signs and symptoms of infections do not change or become worse.

\section{RESULTS}

One hundred and five patients with blood diseases were entered in this study, and 87 patients ( 59 men and 28 women) were eligible for judgement of the efficacy of monotherapy with imipenemcilastatin. Ages of the patients ranged from teens to the eighties. Of the 87 patients, $57.5 \%$ had leukemia and $20.7 \%$ had malignant lymphoma. Ninety percent of all the cases had a hematological malignancy; $60 \%$ of the patients were neutropenic, with a neutrophil count of less than $500 / \mu$ l.

Infections were sepsis, suspected sepsis, pneumonia, respiratory tract infection, urinary tract infection and others. Clinical efficacy of imipenemcilastatin for each type of infection is shown in Table 1. The response rate was expressed by the percentage of the cases judged as excellent or good. The overall response rate to the monotherapy with imipenemcilastatin in this study was $62.1 \%$. Fifty cases were administered a dose of $2 \mathrm{~g} /$ day of imipenem, and showed a response rate of $64 \%$. When $2 \mathrm{~g}$ of imipenem was divided into two administrations a day, the response rate was $68.6 \%$, while when $2 \mathrm{~g}$ of imipenem was divided into 4 times a day the response rate was $53.3 \%$. When imipenem-cilastatin was administered as the first-choice therapy, the response rate was $73.3 \%$. On the other hand, when imipenem-cilastatin was substituted for the preceding ineffective antibiotics, the response rate was $50 \%$.

When neutrophil counts were less than $500 / \mu 1$ during the treatment, the response rate was $62.5 \%$ suggesting that imipenem-cilastatin was effective even though patients were severely neutropenic. Imipenem-cilastatin was effective even when neutrophil counts were less than $100 / \mu l$ during the treatment.

Clinical efficacy and bacteriological follow-up in patients in whom pathogens were identified are shown in Table 2 . The pathogenic bacteria were identified in 27 cases, half of the cases were Grampositive and half Gram-negative. In patients whose pathogens were followed up, all the bacteria except one case of Escherichia coli disappeared by the

Table 1. Clinical efficacy of imipenem-cilastatin in various infections.

\begin{tabular}{|c|c|c|c|c|c|c|}
\hline \multirow{2}{*}{ Infections } & \multirow{2}{*}{$\mathrm{N}$} & \multicolumn{4}{|c|}{ Clinical efficacy } & \multirow{2}{*}{$\begin{array}{l}\text { Response } \\
\text { rate }(\%)\end{array}$} \\
\hline & & Excellent & Good & Partial & Ineffective & \\
\hline Sepsis & 14 & 6 & 3 & 1 & 4 & 64.3 \\
\hline Suspected sepsis & 41 & 11 & 15 & 7 & 8 & 63.4 \\
\hline Pneumonia & 16 & 4 & 4 & 2 & 6 & 50.0 \\
\hline $\begin{array}{l}\text { Respiratory tract } \\
\text { infection }\end{array}$ & 7 & 4 & 1 & 1 & 1 & 71.4 \\
\hline $\begin{array}{l}\text { Urinary tract } \\
\text { infection }\end{array}$ & 7 & 3 & 2 & 1 & 1 & 71.4 \\
\hline Others* & 2 & 1 & 0 & 0 & 1 & 50.0 \\
\hline Total & 87 & 29 & 25 & 12 & 21 & 62.1 \\
\hline
\end{tabular}

* Perianal abscess and otitis media 
Table 2. Clinical and bacteriological efficacy in pathogen-identified cases.

\begin{tabular}{|c|c|c|c|}
\hline Pathogens & $\mathrm{N}$ & $\begin{array}{l}\text { Clinical } \\
\text { response rate }(\%)\end{array}$ & $\begin{array}{l}\text { Disappearance rate } \\
\text { of bacteria }(\%)\end{array}$ \\
\hline S. aureus & 1 & $0 / 1(0)$ & $1 / 1(100)$ \\
\hline S. epidermidis & 6 & $3 / 6(50)$ & $3 / 3(100)$ \\
\hline $\begin{array}{l}\text { Coagulase-negative } \\
\text { staphylococcus (C.N.S.) }\end{array}$ & 1 & $1 / 1(100)$ & N.D. \\
\hline Streptococcus sp. & 1 & $1 / 1(100)$ & N.D. \\
\hline S. agalactiae & 1 & $0 / 1(0)$ & N.D. \\
\hline Enterococcus sp. & 1 & $1 / 1(100)$ & $1 / 1(100)$ \\
\hline E. faecalis & 1 & $0 / 1(0)$ & $1 / 1(100)$ \\
\hline Bacillus sp. & 1 & $1 / 1(100)$ & $1 / 1(100)$ \\
\hline E. coli & 3 & $3 / 3(100)$ & $1 / 2(50)$ \\
\hline E. cloacae & 1 & $1 / 1(100)$ & $1 / 1(100)$ \\
\hline P. aeruginosa & 3 & $2 / 3(66.7)$ & $3 / 3(100)$ \\
\hline P. cepacia & 1 & $0 / 1(0)$ & N.D. \\
\hline E. aerogens & 1 & $0 / 1(0)$ & N.D. \\
\hline $\begin{array}{l}\text { S. aureus }+ \\
P . \text { aeruginosa }\end{array}$ & 1 & $0 / 1(0)$ & N.D. \\
\hline $\begin{array}{l}\text { C.N.S. }+ \\
\text { Actinotobacter sp. }\end{array}$ & 1 & $1 / 1(100)$ & N.D. \\
\hline $\begin{array}{l}\text { Enterococcus sp. + } \\
\text { E. cloacae }\end{array}$ & 1 & $1 / 1(100)$ & N.D. \\
\hline $\begin{array}{l}\text { E. aerogens }+ \\
\text { Neisseria } \mathrm{sp} .\end{array}$ & 1 & $1 / 1(100)$ & N.D. \\
\hline $\begin{array}{l}E . \text { aerogens }+ \\
A . \text { caloaceticus }\end{array}$ & 1 & $0 / 1(0)$ & N.D. \\
\hline Total & 27 & 59.3 & 92.3 \\
\hline
\end{tabular}

N.D., not determined

imipenem-cilastatin administration. Adverse effects were minimal, and skin rashes occurred in only five patients $(4.8 \%$ of the total).

\section{DISCUSSION}

Imipenem is the first antibiotic with a carbapenem ring, and not only has the widest spectrum against aerobic and anaerobic bacteria but also has 
strong bactericidal effects. Cilastatin sodium is a specific antagonist against dehydropeptidase-I which inactivates imipenem in the kidney. Imipenemcilastatin, a complex containing equal amounts of imipenem and cilastatin sodium, is reported to exert excellent in vivo effects on various bacterial infections (4).

In the present study, most cases had a hematological malignancy with severe granulocytopenia. Imipenem-cilastatin monotherapy showed considerable effectiveness against both Gram-positive and Gram-negative bacterial infections, supporting the previous reports of in vitro effectiveness $(5,6)$. When imipenem-cilastatin was administered as the first-choice therapy, the efficacy was much better. Even though patients were severely neutropenic (neutrophil count of less than $500 / \mu 1$, or even less than $100 / \mu 1)$, imipenem-cilastatin was satisfactorily effective. Imipenem-cilastatin was most effective when administered twice a day, suggesting a convenient treatment schedule. Imipenem-cilastatin monotherapy can be recommended as one of the best choices for empiric therapy for various infections accompanying granulocytopenia in hematological malignancies.
ACKNOWLEDGEMENTS: We are grateful to Drs. Y. Miura, N. Aoki, T. Nomura, K. Hirashima, O. Takatani, H. Tokuhiro, K. Toyama, S. Asano, M. Omine, Y. Wakabayashi, I. Aoki, H. Yamaguchi, Y. Mutoh, S. Fujioka, T. Saito, M. Mori, A. Togawa and K. Kinugasa for their cooperation in this study.

\section{REFERENCES}

1) Bodey GP, Buckley M, Sathe YS, et al. Quantitative relationships between circulating leukocytes and infection in patients with acute leukemia. Ann Intern Med 64: 328, 1966.

2) Wiernik PH. The management of infection in the cancer patient. J Am Med Assoc 244: 185, 1980.

3) Boogaerts $M$. Empiric antibiotic therapy in the neutropenic patient. Br J Clin Pract Suppl 57: 85, 1988.

4) Kahan FM, Kropp H, Sundelof JG, et al. Thienamycin: development of imipenem-cilastatin. J Antimicrob Chemother 12: Suppl. D,1, 1983.

5) Williams JD. Activity of imipenem against Pseudomonas and Bacteroides species. Rev Infect Dis 7: Suppl. 3, S411, 1985.

6) Baquero F, Culebras E, Patrón C, et al. Postantibiotic effect of imipenem on Gram-positive and Gram-negative micro-organisms. J Antimicrob Chemother 18: Suppl. E. 47,1986 